\title{
Serum C3 levels in acute glomerulonephritis and postnephritic children
}

\author{
MILANA POPOVIĆ-ROLOVIĆ \\ From the Department of Paediatrics, Medical School, University of Belgrade, and Children's University Hospital, \\ Belgrade, Yugoslavia
}

\begin{abstract}
Popović-Rolović, M. (1973). Archives of Disease in Childhood, 48, 622. Serum C3 levels in acute glomerulonephritis and postnephritic children. Measurements of $\beta_{1} \mathrm{C}$-globulin (C3) by the single radial immunodiffusion method were done in 128 patients with acute glomerulonephritis. In 88 patients the analyses were made during the first 3 weeks of the disease, and sequential determination was done thereafter until the end of the sixth month. During the first 4 weeks of the disease $90 \%$ of the patients had reduced C3 levels and the remaining $10 \%$ had normal levels. In the group of hypocomplementaemic patients only $80 \%$ achieved normal values after 6 months. The initial reduction of C3 concentration did not correlate with the severity of the acute phase of the disease or with the duration of haematuria and proteinuria. In 40 patients the analyses were done 2 to 4 years after the acute phase of the disease (the postnephritic group). $15 \%$ of these patients had a reduced concentration of C3. The mean values of $\mathrm{C} 3$ concentration in this group as a whole was significantly lower than in the control group of 30 healthy children $(P<0 \cdot 001)$.
\end{abstract}

Since it was isolated as a purified protein (MüllerEberhard, Nilsson, and Aronsson, 1960; MüllerEberhard and Nilsson, 1960) $\beta_{1}$ C-globulin (C3) has been measured in a number of patients with various kidney diseases (Borgeaud, Paunier, and Humair, 1970; Gotoff et al., 1965, 1969; Humair, 1968; Morse, Müller-Eberhard, and Kunkel, 1962; Northway et al., 1969; Ogg, Cameron, and White, 1968; Tina et al., 1968; West, Northway, and Davis, 1964; West et al., 1965). Data so far reported indicate that in patients with acute glomerulonephritis $\mathrm{C} 3$ levels are reduced in the first few weeks of the disease (Borgeaud et al., 1970; Gotoff et al., 1965, 1969; Humair, 1968; West et al., 1964). However, sequential determination has not been done extensively except by Humair (1968), and no studies have reported on $\mathrm{C} 3$ levels in the postnephritic period. The significance of normal C3 levels found in some patients with acute glomerulonephritis has not been elucidated (Gotoff et al., 1969; Tina et al., 1968; West et al., 1964) and, moreover, the problem of correlation of the clinical course of the disease with $\mathrm{C} 3$ concentration is still a matter of controversy (Borgeaud et al., 1970; West et al., 1964).

Received 18 January 1973
The purpose of this study was to measure the initial C3 levels in a large group of patients and make sequential determinations during various phases of the disease and in the postnephritic period. It was felt that such investigations would show what proportion, if any, of patients had normal C3 levels and show a possible correlation between the clinical course of the disease and $\mathrm{C} 3$ concentration.

\section{Material and methods}

Measurements of C3 levels were performed in 128 patients with acute glomerulonephritis aged $2 \frac{1}{2}$ to 14 years.

In 88 patients analyses were done during the first 3 weeks of the disease and then they were followed until the end of a 6-month period. These patients were sporadic cases occurring mainly during autumn and spring in 1969 and 1970, and referred to the Children's University Hospital of Belgrade, where they were hospitalized regardless of the severity of the disease. None was from parts of the country with endemic Balkan nephropathy.

Clinical evaluation included complete history and physical examination; culture of the pharynx (or skin) and urine, chest $x$-ray, ECG, hippuran renogram, and laboratory assessment including serum creatinine, urea, and electrolytes, antistreptolysin O titre (ASO), and total haemolytic complement titre, daily urine analysis, and quantitative 24-hour urine protein determination. 
The minimal criteria for diagnosis of acute glomerulonephritis and acceptance into the study were acute onset of the disease without a history of previous renal disease, macroscopical and/or microscopical haematuria with RBC casts and epithelial casts in the urinary sediment, oedema, significantly raised ASO titre $(>200$ Todd units) and, in the absence of the latter, a positive throat or skin culture for group A $\beta$-haemolytic streptococci. In addition, raised blood pressure and signs of reduced glomerular filtration were found in most cases.

Preceding infection was recorded as upper respiratory infection in $82 \%$, skin infection in $10 \%$, and unknown in $8 \%$. The latent period ranged from 4 to 30 days and significantly raised ASO titre was found in $98 \%$. Though throat or skin culture was obtained routinely, data are not presented since almost all the children had received antibiotic therapy before entering hospital. Oedema was shown by subsequent loss of body weight ranging from 5 to $15 \%$ in $96 \%$ of cases, and as a positive history in the remaining $4 \%$. Blood pressure was raised transiently in $90 \%$ of cases. Serum creatinine and urea were raised slightly or moderately (twice normal values) in 37\%, and higher levels were recorded in only $11 \%$.

In 40 children C3 levels were measured 2 to 4 years after the onset of the disease (postnephritic group). In the acute phase of the disease (sporadic cases from 1967-1968) these children were also in hospital for at least 8 weeks and the same criteria for acceptance into the study as was used in the group of 88 patients were applied. None had a history of previous renal disease; in $93 \%$ an earlier upper respiratory infection had been recorded and the ASO titre was significantly raised in $97 \%$. The latent period ranged from 4 to 30 days. Blood pressure was raised in $77 \%$ and oedema was found in $87 \%$. Serum creatinine and urea were slightly or moderately raised in $31 \%$ and higher levels were recorded only in 3\%. All the patients had low levels of haemolytic complement titre.

During routine check-ups of the postnephritic group, in addition to physical examination and blood pressure, the urinary sediment was examined and 24-hour proteinuria determined. When the findings were not within normal limits, endogenous creatinine clearance was determined. In cases in which reduced C3 levels were found, the children were tested again.

C3 concentration was also measured in a control group or 32 healthy children from 3 to 13 years of age.

$\beta_{1} \mathrm{C} /{ }_{1} \mathrm{~A}$ globulin (C3) was determined according to the method of Mancini, Carbonara, and Heremans (1965) by the single radial immunodiffusion technique using commercial Behringwerke partigen plates.

The sera of both patients and healthy children were frozen and analyses were done every 2 to 3 weeks. After thawing, various serum dilutions were put into the wells on the plates and after exposure to room temperature for 48 hours the precipitin diameter was measured. The concentration of $\mathrm{C} 3$ was estimated from the standard curve. Standard sera were also obtained from Behringwerke.

\section{Results}

Concentration of C3 in the control group (32 healthy children) was $109 \cdot 5 \pm 16 \cdot 3 \mathrm{mg} / 100 \mathrm{ml}$ (mean $\pm \mathrm{SD}$ ).

In 88 patients with acute glomerulonephritis studied during the acute phase of the disease, C3 levels were measured in the course of the first 3 weeks of the disease. In the first week levels were measured in 35 patients, in the second week in 31 patients, and the third week in 22 patients.

The results of these investigations show that in $\mathbf{8 0}$ patients $(90 \%)$ C3 levels were reduced during the first 3 weeks of the disease and were normal in 8 patients $(10 \%)$.

Results of sequential determination of serum C3 levels in these patients are shown in Table $I$.

Table II indicates the time required for C3 concentration to become normal.

\section{TABLE I}

Sequential determination of serum C3 levels ( $m g / 100$ $\mathrm{ml}$ ) in patients with acute glomerulonephritis

\begin{tabular}{l|c|c}
\hline \multicolumn{1}{c|}{$\begin{array}{c}\text { Time } \\
\text { period }\end{array}$} & $\begin{array}{c}\text { No. of } \\
\text { patients }\end{array}$ & Mean \pm SD \\
\hline 1st wk & 34 & $26 \cdot 7 \pm 27 \cdot 5$ \\
2nd wk & 32 & $35 \cdot 9 \pm 33 \cdot 9$ \\
3rd wk & 38 & $40 \cdot 2 \pm 34 \cdot 5$ \\
4th wk & 17 & $43 \cdot 8 \pm 25 \cdot 0$ \\
5th-6th wk & 36 & $60 \cdot 5 \pm 26 \cdot 5$ \\
7th-8th wk & 26 & $69 \cdot 2 \pm 23 \cdot 6$ \\
3rd mth & 24 & $80 \cdot 8 \pm 18 \cdot 2$ \\
4th mth & 14 & $89 \cdot 9 \pm 27 \cdot 4$ \\
5th-6th mth & 20 & $99 \cdot 8 \pm 27 \cdot 1$ \\
\hline Control group & 32 & $109 \cdot 5 \pm 16 \cdot 3$ \\
\hline
\end{tabular}

TABLE II

Time taken for serum C3 $(\mathrm{mg} / 100 \mathrm{ml})$ to become normal in patients with acute glomerulonephritis

\begin{tabular}{l|c}
\hline \multicolumn{1}{c|}{ Time period } & $\begin{array}{c}\text { Patients with normal C3 levels } \\
(\%)\end{array}$ \\
\hline 1st, 2nd, 3rd, and 4th wk & 10 \\
5th-6th wk & 35 \\
7th-8th wk & 38 \\
3rd mth & 62 \\
4th mth & 71 \\
5th-6th mth & 80 \\
\hline
\end{tabular}

Despite a marked tendency toward increased concentration and the fact that with the passage of time concentrations increased and became normal in a growing number of patients, not even after 6 months did all the patients show normal C3 levels.

Since the initial reduction of $\mathrm{C} 3$ concentration in the first 3 weeks of the disease varied from 5 to 53 
$\mathrm{mg} / 100 \mathrm{ml}$, the patients were divided into two groups: one with initially markedly reduced levelsbelow $15 \mathrm{mg} / 100 \mathrm{ml}$-and the other with initially slightly reduced levels-from 30 to $53 \mathrm{mg} / 100 \mathrm{ml}$.

Further investigations were done to ascertain (1) whether the initial reduction of concentration was related to the severity of the acute phase of the disease, (2) whether the initial reduction correlated with the duration of proteinuria and haematuria, and (3) whether there was any difference in the outcome of the disease between the two groups.

To estimate the severity of the acute phase of the disease the following clinical and laboratory findings were studied: oedema (estimated as loss of body weight), mean blood pressure, sedimentation rate (Westergren, first 2 hours), serum urea and creatinine levels, haematuria ( $\mathrm{RBC} / \mathrm{hpf}$ ), and 24hour proteinuria. A comparison of these parameters was made between the two groups. The mean values were calculated and the difference was estimated according to Student's ' $t$ ' test. No statistically significant difference between any of the tested parameters was found (from $\mathrm{P}>0 \cdot 10$ to $P>0.90$ ).

The duration of haematuria and proteinuria in these two groups was followed for 1 year and by the end of that time $80 \%$ of the patients in each group showed normal values. A comparison of the duration of haematuria and proteinuria was made between the two groups according to the Wilcoxson, Mann and Whitney U-test and no statistically significant difference was found $(P>0.36$ and $P>0 \cdot 42$, respectively).

Since it was established that in $20 \%$ of patients the serum C3 concentration had not become normal 6 months after the onset of the acute phase of the disease, a group of $\mathbf{4 0}$ children who had recovered from the acute phase of the disease 2 to 4 years earlier were investigated (the postnephritic group). The results of the measurements of $\mathrm{C} 3$ concentration in these children showed that 6 out of $40(15 \%)$ had not achieved normal values within this period either.

In the 6 children with reduced C3 levels the reduction was not pronounced except in one case, the values being $73,70,64,67,64$, and $46 \mathrm{mg} / 100$ $\mathrm{ml}$.

The mean value of $\mathrm{C} 3$ concentration in this group as a whole was lower $(86 \cdot 5 \pm 14 \cdot 8)$ than in the control group, and the difference was statistically significant $(P<0 \cdot 001)$.

During a control examination of the postnephritic children it was found that in 30 all the findings were within normal limits, while in the remaining 10 certain abnormalities were observed, as shown in Table III. All these children had minimal proteinuria and haematuria, while 5 also had reduced C3 levels. Of the total of 6 patients with reduced levels, 5 were in the group 'with sequelae' and only 1 had all findings within normal limits and belonged to the group of 30 children 'with no sequelae'. This child was subjected to analysis twice more within 3 months and C3 values obtained were 41,46 , and $51 \mathrm{mg} / 100 \mathrm{ml}$. Since he showed no other abnormalities, C3 concentration was measured in his parents and one brother and normal values were obtained in all three.

\section{Discussion}

Before individual components of complement were isolated as purified proteins (Müller-Eberhard et al., 1960; Müller-Eberhard and Nilsson, 1960), occasional findings of normal values of haemolytic complement titre in patients with acute glomerulonephritis were not given special attention and were

Postnephritic group: clinical and laboratory findingss

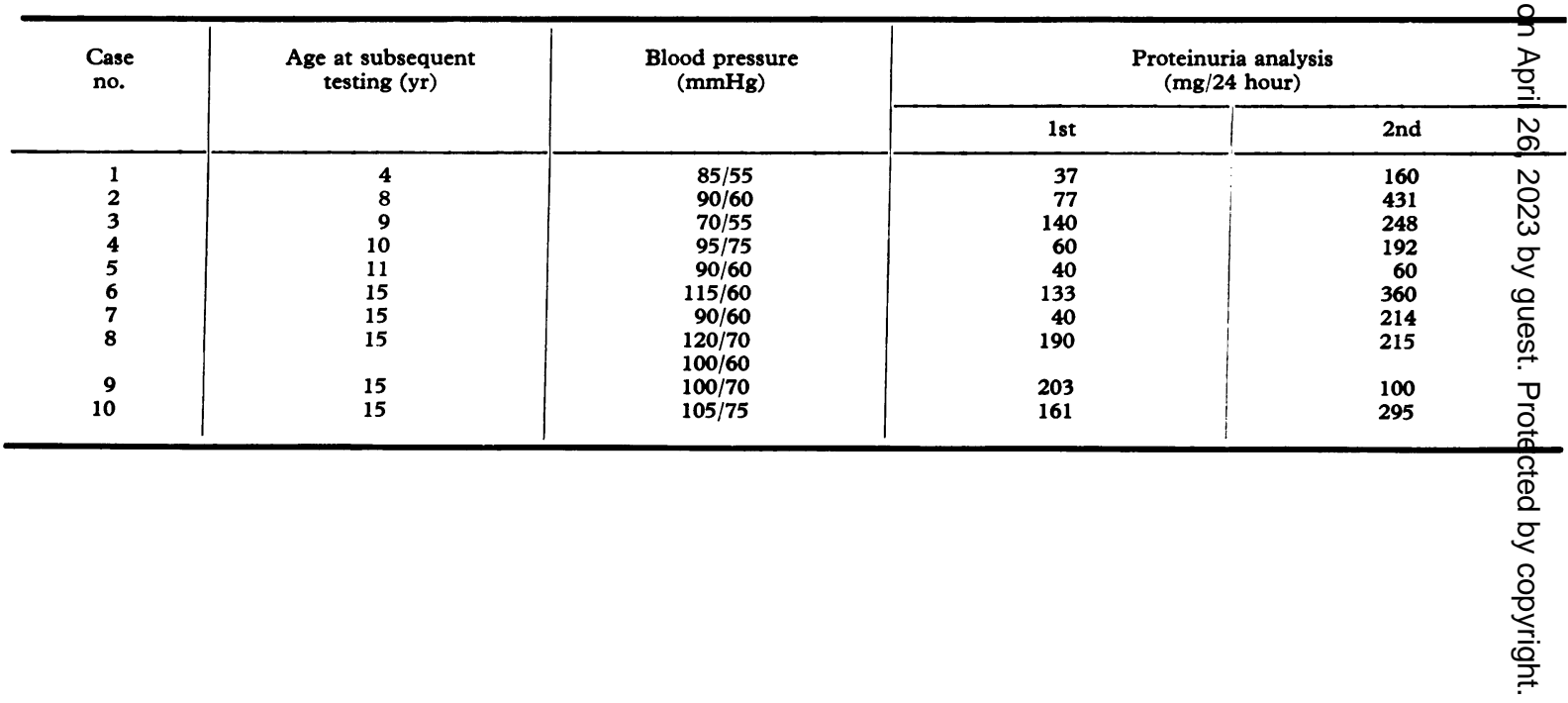


usually attributed to delay in performing the analysis (Fischel and Gajdusek, 1952; Kellett and Thompson, 1939; Lange, Wasserman, and Slobody, 1960; Reader, 1948; Wasserman et al., 1965).

The incidence of normal C3 levels found in patients with acute glomerulonephritis has differed considerably in the various studies so far reported and a different aetiology was suggested as a possible explanation (Tina et al., 1968; West et al., 1964). Gotoff et al. (1969) were the first to prove that two patients with normal C3 levels were typical cases of poststreptococcal glomerulonephritis. In our study it was found that the incidence of normocomplementaemia in a large number of patients with acute glomerulonephrits was $10 \%$. These patients were the subject of a separate study (M. Popović-Rolović, unpublished data) in which it was found that their disease did not differ from typical 'hypocomplementaemic' poststreptococcal glomerulonephritis.

Sequential determination of $\mathrm{C} 3$ levels has been performed in relatively small groups of patients (Borgeaud et al., 1970; Gotoff et al., 1965, 1969) except in the study of Humair (1968); it was found that results became normal within 2 to 4 months. We found that only $80 \%$ of the patients achieved normal values by 6 months. The discrepancy between our findings and the data of Humair (1968) and others (Borgeaud et al., 1970; Gotoff et al., $1965,1969)$ is so far unexplained.

The problem of correlation between complement concentration and the severity of the acute phase of the disease has not been systematically investigated before (Borgeaud et al., 1970; Fischel and Gajdusek, 1952; Kellett and Thompson, 1939; Lange et al., 1960; Reader, 1948; West et al., 1964). Our study has proved, by comparing clearly defined parameters of the acute phase of the disease, that the initial reduction of $\mathrm{C} 3$ levels does not correlate with the severity of the acute phase. Our findings also indicate that the initial reduction probably does not influence the final outcome of the disease.

We know of no previous investigations of $\mathrm{C} 3$ concentration in patients several years after the acute phase of their disease (postnephritic children). Our data indicate that not even after this period do all the patients have normal concentrations. The possibility that some of our patients with reduced C3 levels were in reality suffering from exacerbations of chronic glomerulonephritis from the beginning of the disease could not be ruled out completely without renal biopsy (Edelmann, Greifer, and Barnett, 1964). However, this possibility seems very unlikely because these patients were followed closely during the acute phase of the disease and thereafter, and the course of their disease did not differ from that of the others. The mean concentration of $\mathrm{C} 3$ in this group as a whole was significantly lower $(P<0.001)$ than in the control group of healthy children.

Reduced C3 levels in this group may be due to three causes. (1) That complement is still being consumed by the creation of immune complexes (Michael et al., 1966); (2) the impaired relation between synthesis and catabolism which seems to exist in the acute phase of the disease (Alper and Rosen, 1967) may last considerably longer; and (3) it is possible that inhibitors of complement also continue to be produced for a long time or are periodically activated as a kind of protective mechansim (Pickering, Gewurz, and Good, 1968). Obviously this problem cannot be resolved without parallel investigation of the metabolism of $\mathrm{C} 3$ and analysis of the biopsy materials for ultrastructural and immunohistological changes.

From the practical point of view, one should not forget that children affected by acute glomerulo-

ut control examination in 10 patients with sequelae

\begin{tabular}{|c|c|c|c|c|c|}
\hline \multicolumn{2}{|c|}{$\begin{array}{l}\text { Urinary sediment } \\
\text { analysis (RBC/hpf) }\end{array}$} & \multirow[t]{2}{*}{$\begin{array}{l}\text { Creatinine clearance } \\
\left(\mathrm{ml} / \mathrm{min} \text { per } 1 \cdot 73 \mathrm{~m}^{2}\right)\end{array}$} & \multicolumn{2}{|c|}{$\begin{array}{l}\text { Serum C3 analysis } \\
(\mathrm{mg} / 100 \mathrm{ml})\end{array}$} & \multirow[t]{2}{*}{ Outcome } \\
\hline 1st & 2nd & & 1st & 2nd & \\
\hline $\begin{array}{c}0-1 \\
0-1 \\
0 \\
0-2 \\
4-6 \\
0 \\
0-1 \\
0\end{array}$ & $\begin{array}{c}0 \\
0 \\
0 \\
0 \\
0-2 \\
0 \\
0 \\
0\end{array}$ & $\begin{array}{l}105 \\
105 \\
102 \\
120 \\
168 \\
130 \\
163 \\
115\end{array}$ & $\begin{array}{r}64 \\
76 \\
72 \\
110 \\
100 \\
70 \\
60 \\
56\end{array}$ & $\begin{array}{l}70 \\
80 \\
75\end{array}$ & $\begin{array}{l}\text { Intermittent proteinuria } \\
\text { Intermittent proteinuria } \\
\text { Constant proteinuria } \\
\text { Intermittent proteinuria } \\
\text { Intermittent haematuria } \\
\text { Constant proteinuria } \\
\text { Intermittent proteinuria } \\
\text { Constant proteinuria }\end{array}$ \\
\hline $\begin{array}{l}0-1 \\
0-1\end{array}$ & $\begin{array}{l}\mathbf{0} \\
\mathbf{0}\end{array}$ & $\begin{array}{l}145 \\
135\end{array}$ & $\begin{array}{r}80 \\
100\end{array}$ & & $\begin{array}{l}\text { Intermittent proteinuria } \\
\text { Constant proteinuria }\end{array}$ \\
\hline
\end{tabular}


nephritis have a favourable prognosis (ČalićPerišić et al., 1968; Dodge et al., 1962; Edelmann et al., 1964; Perlman et al., 1965). We consider that our results contibute towards the elucidation of the natural course of the disease in acute glomerulonephritis and that for the time being there is not enough evidence for interpreting a low serum C3 concentration as an unfavourable prognostic sign.

I am grateful to Professor Dr. O. M. Wrong and Dr. D. D. Peters for help in preparing this paper. This study was partly supported by grant No. 120/72 from the Association of Medical Research Institutions of the Socialist Republic of Serbia.

\section{REFERENCES}

Alper, C. A., and Rosen, F. S. (1967). Studies of the in vivo behaviour of human $C^{\prime} 3$ in normal subject and patients. fournal of Clinical Investigation, 46, 2021.

Borgeaud, M., Paunier, L., and Humair, M. (1970). La beta $1_{C^{-}}$ globuline dans les néphropathies de l'enfant. Helvetica Paediatrica Acta, 25, 585.

Calič-Perišic, N., Djukic, D., Rolovic, M., Kostić, S., and Djuknić, V. (1968). Prognosis of acute glomerulonephritis in children. Serbian Archives of General Medicine, 86, 581.

Dodge, W. F., Daeschner, C. W., Jr., Brennan, J. C., Rosenberg, H. S., Travis, L. B., and Hopps, H. C. (1962). Percutaneous renal biopsy in children. II. Acute glomerulonephritis, chronic glomerulonephritis, and nephritis of anaphylactoid purpura. Pediatrics, 30, 237.

Edelmann, C. M., Jr., Greifer, I., and Barnett, H. L. (1964). The nature of kidney disease in children who fail to recover from apparent acute glomerulonephritis. Fournal of Pediatrics, 64, 879.

Fischel, E. E., and Gajdusek, D. C. (1952). Serum complement in acute glomerulonephritis and other renal diseases. American Fournal of Medicine, 12, 190.

Gotoff, S. P., Fellers, F. X., Vawter, G. F., Janeway, C. A., and Rosen, F. S. (1965). The betalc globulin in childhood nephrotic syndrome: laboratory diagnosis of progressive glomerulonephritis. New England fournal of Medicine, 273, 524.

Gotoff, S. P., Isaacs, E. W., Muehrcke, R. C., and Smith, R. D. (1969). Serum beta1c globulin in glomerulonephritis and systemic lupus erythematosus. Annals of Internal Medicine, 71, 327.

Humair, L. M. (1968). Beta-1 $\mathrm{C}^{-g}$ globulin and complement in nephritis. Helvetica Medica Acta, 34, 279.

Kellett, C. E., and Thompson, J. G. (1939). Complementary activity of blood serum in nephritis. Fournal of Pathology, 48, 519.
Lange, K., Wasserman, E., and Slobody, L. B. (1960). Significance of serum complement levels for the diagnosis and prognosis of acute and subacute glomerulonephritis and lupus erythematosus disseminatus. Annals of Internal Medicine, 53, 636.

Mancini, G., Carbonara, A. O., and Heremans, J. F. (1965). Immunochemical quantitation of antigens by single radial immunodiffusion. Immunochemistry, 2, 235.

Michael, A. F., Drummond, K. N., Good, R. A., and Vernier, R. L. (1966). Acute poststreptococcal glomerulonephritis: immune deposit disease. Fournal of Clinical Investigation, 45, 237.

Morse, J. H., Müller-Eberhard, H. J., and Kunkel, H. G. (1962). Antinuclear factors and serum complement in systemic lupus erythematosus. Bulletin of the New York Academy of Medicine, 38,641 .

Müller-Eberhard, H. J., and Nilsson, U. (1960). Relation of a beta 1 -glycoprotein of human serum to the complement system. Fournal of Experimental Medicine, 111, 217.

Müller-Eberhard, H. J., Nilsson, U., and Aronsson, T. (1960). Isolation and characterization of two beta 1 -glycoproteins of human serum. Fournal of Experimental Medicine, 111, 201.

Northway, J. D., McAdams, A. J., Forristal, J., and West, C. D. (1969). A 'silent' phase of hypocomplementemic persistent nephritis detectable by reduced serum beta $1 \mathrm{c}-$ globulin levels. Fournal of Pediatrics, 74, 28.

Ogg, C. S., Cameron, J. S., and White, R. H. R. (1968). The C'3 component of complement (beta $1_{C}$-globulin) in patients with heavy proteinuria. Lancet, $2,78$.

Perlman, L. V., Herdman, R. C., Kleinman, H., and Vernier, R. L. (1965). Poststreptococcal glomerulonephritis. Fournal of the American Medical Association, 194, 63.

Pickering, R. J., Gewurz, H., and Good, R. A. (1968). Complement inactivation by serum from patients with acute and hypocomplementemic chronic glomerulonephritis. Fournal of Laboratory and Clinical Medicine, 72, 298.

Reader, R. (1948). Serum complement in acute nephritis. British Fournal of Experimental Pathology, 29, 255.

Tina, L. U., D'Albora, J. B., Antonovych, T. T., Bellanti, J. A., and Calcagno, P. L. (1968). Acute glomerulonephritis associated with normal serum beta ${ }_{1}$ C-globulin. American fournal of Diseases of Children, 115, 29.

Wasserman, E., Schwarz, F., Wachstein, M., and Lange, K. (1965). Diagnostic value of serum complement determination in hereditary glomerulonephritis. Fournal of Laboratory and Clinical Medicine, 65, 589.

West, C. D., McAdams, A. J., McConville, J. M., Davies, N. C., and Holland, N. H. (1965). Hypocomplementemic and normocomplementemic persistent (chronic) glomerulonephritis; clinical and pathologic characteristics. Fournal of Pediatrics, 67, 1089.

West, C. D., Northway, J. D., and Davis, N. C. (1964). Serum levels of beta ic globulin, a complement component, in the nephritides, lipoid nephrosis, and other conditions. Fournal of Clinical Investigation, 43, 1507.

Correspondence to Dr. M. Popović-Rolović, Beograd, Dečja klinika, Tiršova 10, Yugoslavia. 